\title{
Evaluasi Kesesuaian Pemanfaatan Pola Ruang Kota Baubau (Studi Kasus: Kecamatan Batupoaro, Murhum dan Wolio)
}

\author{
Asnawati Izat ${ }^{1)}$, La Ode Restele ${ }^{2)}$, Jamal Harimuddin ${ }^{2)}$ \\ ${ }^{1)}$ Program Studi Geografi Fakultas Ilmu dan Teknologi Kebumian UHO \\ 2) Jurusan Geografi Fakultas Ilmu dan Teknologi Kebumian UHO \\ Email: ${ }^{1}$ asnawati.izat@gmail.com, ${ }^{2}$ naufal_ldrestele@yahoo.com, \\ jamalharimudin@gmail.com
}

\begin{abstract}
Abstrak: Kota Baubau yang terus berkembang mengakibatkan pesatnya pertumbuhan penduduk dan peningkatan kebutuhan lahan sehingga cenderung mempengaruhi pola ruang wilayah kota. Penelitian ini bertujuan untuk: (1) mengetahui berapa besar penyimpangan pemanfaatan pola ruang; (2) mengetahui faktor-faktor yang mempengaruhi penyimpangan pemanfaatan pola ruang. Metode analisis data yang digunakan dalam penelitian ini: (1) analisis overlay dan analisis kesesuaian pemanfaatan pola ruang untuk melihat tingkat kesesuaian pemanfaatan pola ruang dan mengetahui besaran penyimpangan pemanfaatan pola ruang; (2) analisis regresi berganda dengan variabel dummy untuk melihat faktor-faktor yang mempengaruhi penyimpangan pola ruang. Hasil penelitian antara lain: (1) besaran klasifikasi luas lahan yang sesuai terhadap rencana tata ruang di lokasi penelitian (Kecamatan Batupoaro, Murhum dan Wolio) adalah seluas 2.438 ha (67\%), klasifikasi belum terbangun seluas 1.097 ha (30\%), dan klasifikasi tidak sesuai atau menyimpang seluas 104 ha (3\%) dari luas wilayah perencanaan; (2) faktor yang paling signifikan mempengaruhi penyimpangan pola ruang adalah faktor perizinan.
\end{abstract}

\section{Kata Kunci: Evaluasi, Kesesuaian, Pola Ruang}

\begin{abstract}
Baubau City that continues to grow resulted in rapid population growth and increased land requirements so it tends to affect the spatial pattern of urban areas. This study aims to: (1) know how much the use of spatial pattern deviations; (2) know the factors that influence the deviation in the use of spatial patterns. Data analysis methods used in this study: (1) overlay analysis and analysis of suitability of spatial patterns utilization to know the level of suitability of spatial pattern utilization and know magnitude of spatial pattern deviation; (2) multiple regression analysis with dummy variables to know the factors that influence spatial pattern deviations. The results of the study are: (1) the amount of land area classification according to the spatial plan at the study site (Batupoaro, Murhum and Wolio Districts) is 2,438 acre $(67 \%)$, the undeveloped classification is 1,097 acre $(30 \%)$, and the classification is not according to or deviating area of 104 acre $(3 \%)$ of the planning area; (2) the most significant factor affecting spatial pattern deviations is the licensing factor.
\end{abstract}

Keywords: Evaluation, Suitability, Spatial Pattern 


\section{PENDAHULUAN}

Pemanfaatan pola ruang wilayah kota pada dasarnya harus memperhatikan keseimbangan antar kebutuhan dengan daya dukung lingkungan dalam menyediakan sumberdaya (carrying capacity). Undang-undang No.26 Tahun 2007, tentang penataan ruang mengamanatkan bahwa perlunya suatu perencanaan yang mengharuskan setiap daerah untuk membuat konsep penataan ruang agar kualitas ruang setiap daerah dapat terjaga keberlanjutannya, namun kecenderungan penyimpangan terhadap tata ruang yang telah ditetapkan disetiap daerah masih sering terjadi karena berbagai faktor yang secara umum disebabkan adanya kebutuhan tempat tinggal bagi penduduk maupun untuk aktivitas pembangunan lainnya.

Kota Baubau yang memiliki potensi untuk pengembangan pariwisata juga sebagai kawasan yang potensial untuk pengembangan sarana dan prasarana transportasi laut sangat mendukung interaksi antar wilayah dan peningkatan laju pertumbuhan ekonomi, hal ini berimplikasi terhadap peningkatan pembangunan dan kebutuhan akan ruang sehingga cenderung mempengaruhi penyimpangan atau ketidak optimalan pencapaian pemanfaatan pola ruang sebagaimana yang telah di rencanakan.

Muhajir (2017) ketersediaan ruang kota terbatas sementara dinamika kebutuhan ruang sangat tinggi dianggap sebagai penyebab penataan ruang di Kota Baubau belum berjalan sebagaimana yang diharapkan. Banyak hambatan serta penyimpangan baik dari masyarakat maupun pemerintah sendiri sehingga indikator capaian pemanfaatan ruang dan kawasan yang memiliki dokumen perencanaan belum optimal.

Pencapaian rencana pemanfaatan ruang yang belum optimal di Kota Baubau sejalan dengan peningkatan jumlah penduduk dan kebutuhan ruang. Berdasarkan data antara Badan Pusat Statistik Kota Baubau Tahun 2015 dan 12 --- April
Badan Pusat Statistik Kota Baubau Tahun 2018 menunjukkan jumlah penduduk di lokasi penelitian terus mengalami peningkatan yaitu di Kecamatan Batupoaro, Kecamatan Murhun dan Kecamatan Wolio berturut-turut pada tahun 2014 berjumlah 28.648 jiwa, 21.311 jiwa dan 41.948 jiwa, sedangkan pada tahun 2017 berjumlah 30.802 jiwa, 22.918 jiwa dan 45.008 jiwa. Dinamika pertumbuhan penduduk yang mempengaruhi kecenderungan peningkatan pembangunan di tiga kecamatan tersebut menjadi dasar penelitian ini yaitu untuk mengevaluasi kesesuaian pemanfaatan pola ruang Kota Baubau khususnya pada Kecamatan Batupoaro, Murhum dan Wolio. Tujuan dari penelitian ini yaitu mengetahui berapa besar penyimpangan pemanfaatan pola ruang; dan mengetahui faktor-faktor yang mempengaruhi penyimpangan pemanfaatan pola ruang.

\section{METODE PENELITIAN}

Lokasi penelitian ini berada di Kecamatan Wolio, Murhum dan Batupoaro Kota Baubau Provinsi Sulawesi Tenggara (Gambar 1).

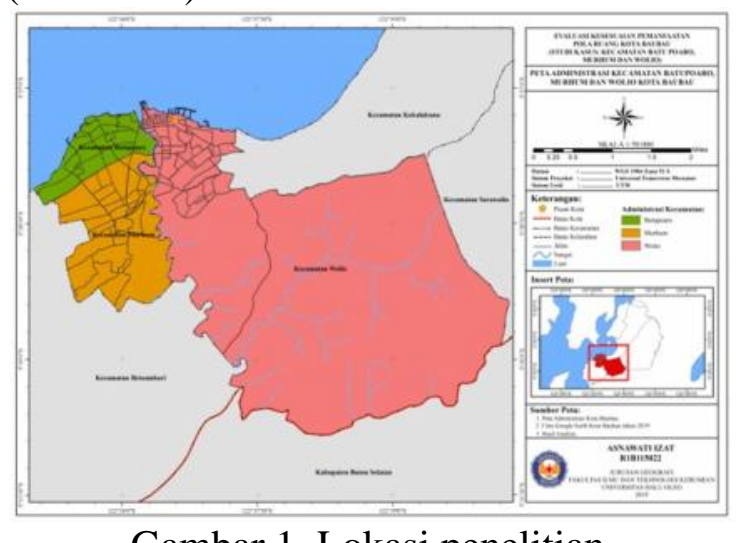

Gambar 1. Lokasi penelitian

\subsection{Tahap Pengolahan Data}

Sebelum melakukan analisis data untuk menjawab masalah dan tujuan penelitian, terlebih dahulu data disiapkan melalui tahapan pengolahan data.

\section{Pembuatan Peta Lokasi Penelitian}


Pembuatan peta lokasi penelitian diolah dengan mengekstrak data dari peta administrasi Kota Baubau tahun 2017. Informasi yang diperoleh adalah batas administrasi masing-masing Kecamatan dalam lokasi penelitian yaitu Kecamatan Wolio, Kecamatan Murhum daa Kecamatan Batupoaro.

\section{Interpretasi Citra Google Earth}

Interpretasi citra Google Earth perlu dilakukan pada penelitian ini guna mengidentifikasi implementasi pemanfaatan ruang aktual. Interpretasi citra dilakukan secara visual untuk mengidentifikasi pemanfaatan ruang aktual yang meliputi kawasan lindung dan kawasan budidaya berdasarkan unsurunsur klasifikasi pemanfaatan pola ruang yang terdapat pada rencana tata ruang kota Baubau.

\section{Uji akurasi}

Penentuan sampel untuk menguji keakuratan hasil interpretasi citra pada pembuatan peta penggunaan lahan aktual ditentukan berdasarkan skala peta. Rumus yang digunakan untuk mengetahui jumlah sampel minimal dalam total luas lahan (ha) ditentukan berdasarkan Pedoman Teknis Data Geospasial Mangrove (2014) yaitu:

$A=\mathrm{TSM}+\frac{\mathrm{L} \quad(\mathrm{H})}{1}$

\section{Keterangan:}

A : Jumlah Sampel Minimal

TSM : Total Sampel Minimal

Tabel 1.Jumlah Sampel Berdasarkan Skala Peta

\begin{tabular}{cc}
\hline Skala & $\begin{array}{c}\text { Total Sampel } \\
\text { Minimal (TSM) }\end{array}$ \\
\hline $1: 25.000$ & 50 \\
\hline $1: 50.000$ & 30 \\
\hline $1: 250.000$ & 20 \\
\hline
\end{tabular}

Sumber: Pedoman Teknis Data Geospasial Mangrove Tahun 2014

Uji akurasi hasil klasifikasi citra dilakukan untuk menguji tingkat akurasi peta pemanfaatan ruang aktual berdasarkan jumlah sampel yang telah ditentukan sebelumnya. Klasifikasi citra dianggap benar jika hasil perhitungan confusion matrix $\geq 80 \%$ (Short, 1982 dalam Nawangwulan (2013). Adapun rumus untuk menentukan ketelitian klasifiksi merujuk pada Mizan (2017) yang dituliskan sebagai berikut:

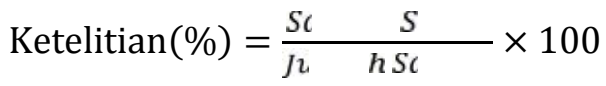

\section{Re-produksi Data Spasial}

Reproduksi data spasial dalam penelitian ini merupakan mereproduksi data Peta Rencana Pola Ruang Kota Bubau tahun 2014-2034. Dengan melakukan georeferencing dan kemudian digitasi. Digitasi peta merupakan pekerjaan memindahkan peta (hardcopy) dalam bentuk lembaram peta kedalam computer (format shp).

\section{Tabulasi Data Kuesioner}

Tabulasi data dilakukan untuk memudahkan proses analisis data hasil kuesioner untuk melihat faktor-faktor yang berpengaruh terhadap peyimpangan pemanfaatan pola ruang wilayah Kecamatan Batupoaro, Murhun dan Wolio Kota Baubau.

\subsection{Metode Analisis}

Teknik analisis yang digunakan adalah analisis overlay dan analisis kesesuaian pemanfaatan pola ruang untuk menjawab tujuan pertama dan analisis regresi berganda dengan variabel dummy untuk menjawab tujuan kedua.

\section{Analisis Overlay}

Proses Overlay dalam penelitian ini adalah union untuk memperoleh informasi mengenai kesesuaian peta pemanfaatan ruang aktual dengan peta rencana pola ruang Kota Baubau tahun 2014-2034 pada setiap atribut yang sama. Proses analisis ini dilakukan untuk mengetahui besarnya penyimpangan pemanfaatan pola ruang. 


\section{Analisis Kesesuaian Pemanfaatan Pola Ruang}

Analisis kesesuaian pemanfaatan pola ruang dilakukan menggunakan hasil overlay peta pemanfaatan ruang aktual dan peta rencana pola ruang sebagai instrumen yang akan dilihat kesesuaiannya. Hasil yang didapatkan yaitu peta kesesuaian pemanfaatan pola ruang Kecamatan Batupoaro, Murhum dan Wolio dengan klasifikasi sesuai, tidak sesuai dan kawasan belum terbangun atau belum termanfaatkan sesuai perencanaan.

Hasil dari analisis spasial berupa luasan penggunaan lahan yang menyimpang/tidak sesuai dengan rencana pola ruang kemudian diterjemahkan ke dalam rentang nilai kuantitatif dari rendah hingga tinggi menggunakan dasar Pedoman Pemantauan dan Evaluasi Pemanfaatan Ruang Wilayah Kota Berbasis Sistem Informasi Geografis (Peraturan Direktorat Jenderal Penataan Ruang Kementrian Pekerjaan Umum, 2010). Dalam teknik kuantifikasi penilaian kualitatif ini dibuat dalam ukuran kuantitatif dengan skala 4 (nilai 0 sampai dengan 4), dimana 0 menunjukkan angka terendah (yang berarti terjadi tidak ada kesesuaian) dan 4 menunjukkan angka tertinggi (yang berarti telah sesuai), dengan klasifikasi sebagai berikut:

- >99\% : tidak ada kesesuaian dengan nilai 0

- 50\% - < 99\% : Simpangan tinggi dengan nilai 1

$-25 \%-<50 \%$ : Simpangan sedang dengan nilai 2

$-1 \%-<25 \%$ : Simpangan rendah dengan nilai 3

- $0 \%-<1 \%$ : Kesesuaian sempurna dengan nilai 4

\section{Analisis Regresi Berganda dengan Variabel Dummy}

Bentuk rumusan matematik dalam penelitian ini menggunakan analisis regresi berganda untuk mengetahui penyimpangan pemanfaatan pola ruang sebagai variabel terikat (dependen) 14 --- April terhadap variabel-variabel bebas (independen) yang mempengaruhinya seperti sosialisasi tata ruang, perizinan dan sanksi penataan ruang. Secara umum hubungan antara variabel-variabel tersebut dapat dirumuskan dalam bentuk persamaan sebagai berikut (Sulistyono dan Sulistiyowati, 2018):

$\mathrm{Y}=\alpha+\beta_{1} \mathrm{D}_{1}+\beta_{2} \mathrm{D}_{2}+\beta_{3} \mathrm{D}_{3}+\varepsilon \mathrm{i}$

\section{Keterangan:}

Y:Penyimpangan Pemanfaatan Pola Ruang $\boldsymbol{\alpha}:$ Konstanta

$\boldsymbol{\beta 1}$ koefisien regresi dari (D1)

及2. koefisien regresi dari (D2)

及3:koefisien regresi dari (D3)

D1:Sosialisasi Tata Ruang sebagai variabel

Dummy (skors)

D:1 jika ada sosialisasi tata ruang

D:0 jika tidak ada sosialisasi tata ruang

D2: Perizinan

D:1 jika membuat izin membangun

D:0 jika tidak membuat izin membangun

D3: Sanksi Penataan Ruang

D:1 jika mengetahui adanya Sanksi Penataan Ruang

D:0 jika tidak mengetahui adanya Sanksi Penataan Ruang

Nilai yang digunakaan untuk mengetahui variabel penyimpangan pemanfaatan pola ruang akan diukur menggunakan skala Likert yaitu pemberian skor dengan membentuk lima kategori jawaban yang dinyatakan dengan bilangan bulat 1,2,3,4 dan 5. Skor tertinggi adalah 5 untuk jawaban yang paling diharapkan dan skor terendah adalah 1 untuk jawaban yang paling tidak diharapkan. Dalam pengolahan data dilakukan beberapa pengujian, yaitu uji determinasi $\left(\mathrm{R}^{2}\right)$, uji signifikan simultan (uji-F) dan Uji signifikansi koefisien regresi $(\beta)$. Analisis ini dilakukan untuk melihat faktor-faktor yang mempengaruhi penyimpangan pola ruang. 


\section{HASIL DAN PEMBAHASAN}

\subsection{Rencana Pola Ruang}

Kota Baubau khususnya pada Kecamatan Batupoaro, Murhum dan Wolio yang menjadi fokus lokasi dalam penelitian ini merupakan kecamatan yang berpotensi mengalami perkembangan, sehingga dalam pengendaliannya perlu rencana pemanfaatan pola ruang yang menjadi salah satu bagian dari RTRW Kota Baubau tahun 2014-2034. Rencana pemanfaatan ruang ini disusun dengan tujuan untuk mewujudkan ruang wilayah kota yang aman, nyaman, produktif dan berkelanjutan.

Rencana pola ruang yang dibuat khususnya pada lokasi penelitian sangat didominasi oleh peruntukan kawasan budidaya, antara lain hutan produksi, pelabuhan, kawasan pendidikan, perdagangan dan jasa, perkantoran, perguruan tinggi, kawasan pertanian dan perumahan keseluruhannya seluas $2.252,14$ ha atau mencapai $62 \%$ dari luas wilayah penelitian, dan didominasi untuk rencana kawasan perumahan yaitu seluas $1.448,35$ ha atau mencapai $40 \%$ dari luas lokasi penelitian.

Rencana kawasan lindung antara lain kawasan cagar budaya, ruang terbuka hijau, hutan lindung dan sungai keseluruhannya seluas $1.386,5$ ha atau mencapai $38 \%$ dari luas lokasi penelitian. Kawasan hutan lindung dalam perencanaannya juga diperuntukan dalam cakupan wilayah yang besar seluas $1.018,39$ ha atau mencapai $28 \%$ dari luas lokasi penelitian (Gambar 2).

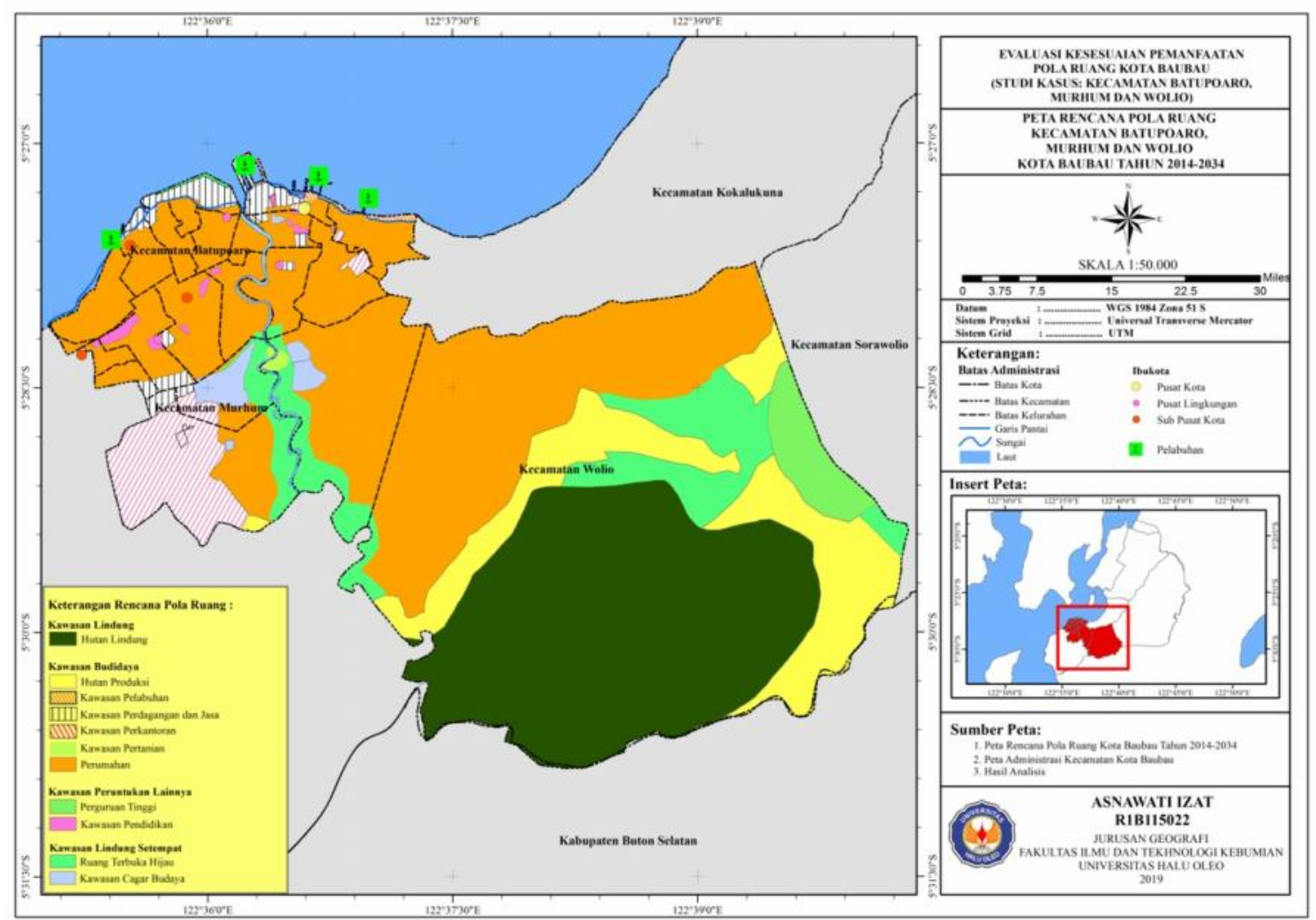

Gambar 2. Peta Rencana Pola Ruang Kecamatan Batupoaro,Murhum dan Wolio Kota Baubau Tahun 2014-2034

\subsection{Pemanfaatan Ruang Aktual}

Kawasan terbangun pada pemanfaatan ruang aktual berdasarkan hasil interpretasi citra 2019 meliputi kawasan perumahan, perkantoran, perdagangan dan jasa, pendidikan, kawasan cagar budaya, pergudangan, pelabuhan dan perguruan tinggi, sedangkan ruang terbuka meliputi kawasan hutan, pertanian, kebun 
campuran, lahan terbuka, ruang terbuka hijau, semak belukar dan sungai, kawasan

non terbangun yang mendominasi pada lokasi penelitian adalah kawasan hutan seluruhnya seluas $2.081,7$ ha atau sebesar $57 \%$ dari luas wilayah penelitian,
Sedangkan pada kawasan terbangun yang mendominasi adalah kawasan perumahan yaitu seluas 608,23 ha atau sebesar $17 \%$ dari luas wilayah penelitian. Adapun lebih jelasnya pola pemanfatan ruang aktual dapat dilihat pada Gambar 3.

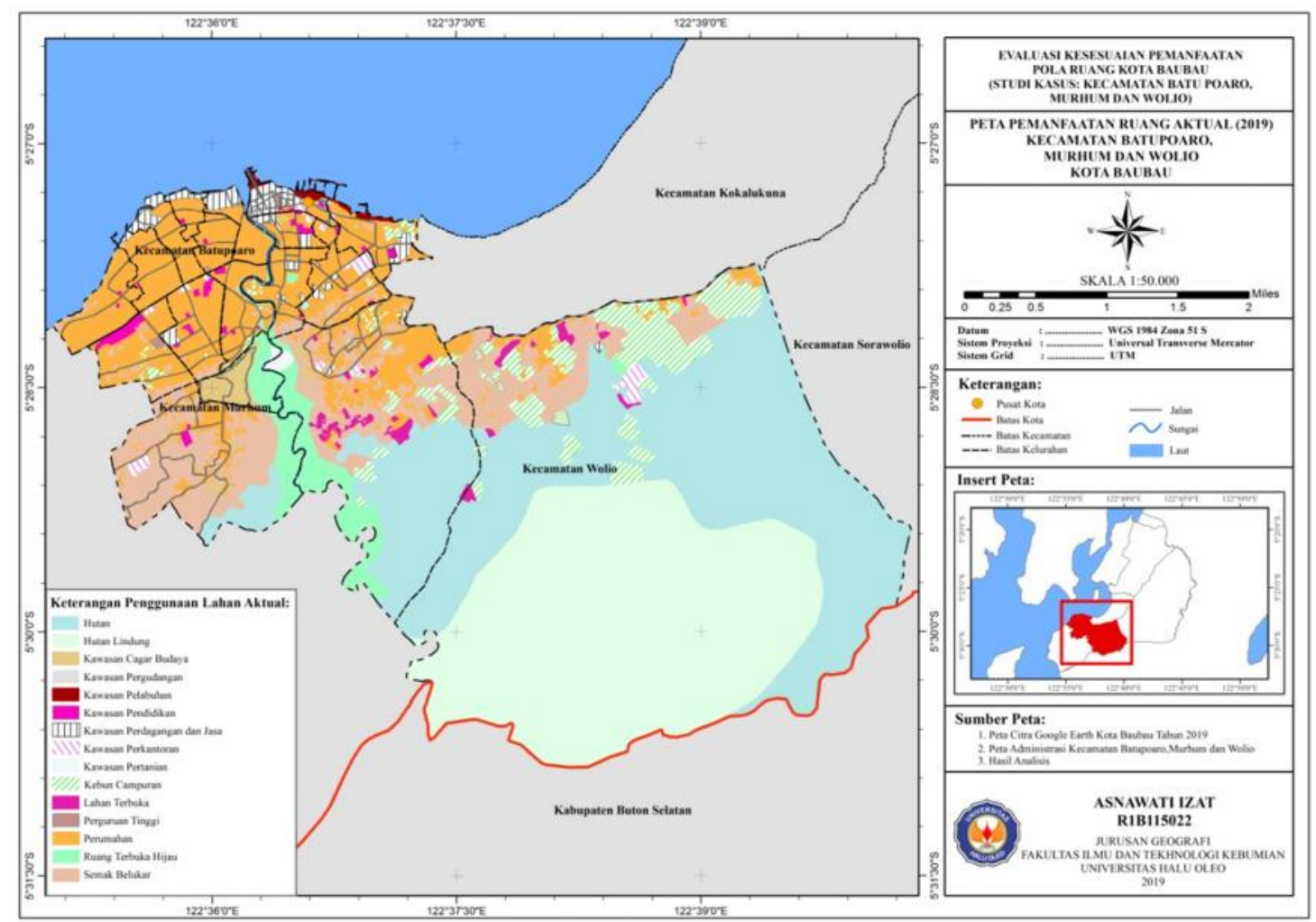

Gambar 3. Peta Pemanfaatan Ruang Aktual Kecamatan Batupoaro,Murhum dan Wolio Kota Baubau Tahun 2019

\subsection{Uji Akurasi Hasil Interpretasi}

Berdasarkan hasil pengolahan tabel confusion matrix yang telah dilakukan, didapatkan tingkat ketelitian diperoleh dari pembagian antara jumlah sampel yang sesuai (53 sampel) pada hasil observasi lapangan dibagi dengan jumlah sampel keseluruhan yang diambil (55 sampel) dan dikali dengan 100 , sehingga hasil uji akurasi pemanfaatan ruang aktual menggunakan metode confusion matrix menujukkan hasil perhitungan tingkat ketelitian peta pemanfaatan ruang aktual hasil interpretasi citra adalah 96\%, maka hasil interpretasi dapat digunakan untuk analisis lebih lanjut sebagaimana yang telah dikemukakan sebelumya bahwa data hasil interpretasi dapat digunakan apabila 16 --- April nilai dari hasil uji akurasi mencapai $80 \%$. Kesalahan interpretasi dikarenakan kenampakan visual kebun campuran dan semak belukar yang terkadang sulit untuk dibedakan sehingga terjadi kekeliruan pengenalan objek.

\subsection{Kesesuaian Pemanfaatan Ruang Aktual Tahun 2019 Terhadap Rencana Pola Ruang Tahun 2014-2034}

Kegiatan analisis kesesuaian pemanfaatan pola ruang pada penelitian ini hanya memanfaatkan hasil analisis overlay antara peta pemanfaatan ruang aktual tahun 2019 dan peta rencana pola ruang tahun 2014-2034 sebagai instrument pembantu, maka hasil dari analisis overlay berupa luasan-luasan perbandingan antara peta tersebut merupakan sebuah asumsi 
karena pada penelitian ini tidak menggunakan dasar aturan lainya yang mengatur pemanfaatan ruang pada lokasi penelitian.

Kesesuaian pemanfaatan ruang dilakukan dengan membandingkan kondisi pemanfaatan ruang aktual terhadap rencana yang menghasilkan perolehan data informasi kesesuaian dengan tiga kriteria yaitu pemanfaatan ruang sesuai, tidak sesuai dan pemanfaatan ruang belum terbangun.

Hasil berdasarkan analisis overlay dan analisis kesesuaian pemanfaatan pola ruang antara peta pemanfaatan ruang aktual (2019) dan peta rencana pola ruang (2014-2034) di Kecamatan Batupoaro,
Murhum dan Wolio, didapatkan besaran pemanfaatan ruang sesuai yaitu seluas 2.248 ha $(62 \%)$ dari luas wilayah rencana. Sedangkan pemanfaatan ruang yang belum terbangun sesuai dengan pola perencanaan yang telah ditentukan masih cukup mendominasi yaitu secara keseluruhan seluas 1.097 ha (30\%) dari luas wilayah perencanaan dan masih berupa kawasan semak belukar, kebun campuran, lahan terbuka, laut atau hutan. Adapun besaran pemanfaatan ruang tidak sesuai atau menyimpang, didapatkan seluas 104 ha (3\%) dari luas wilayah rencana. Besaran kesesuaian untuk setiap indikator rencana pola ruang dapat dilihat pada Gambar 4.

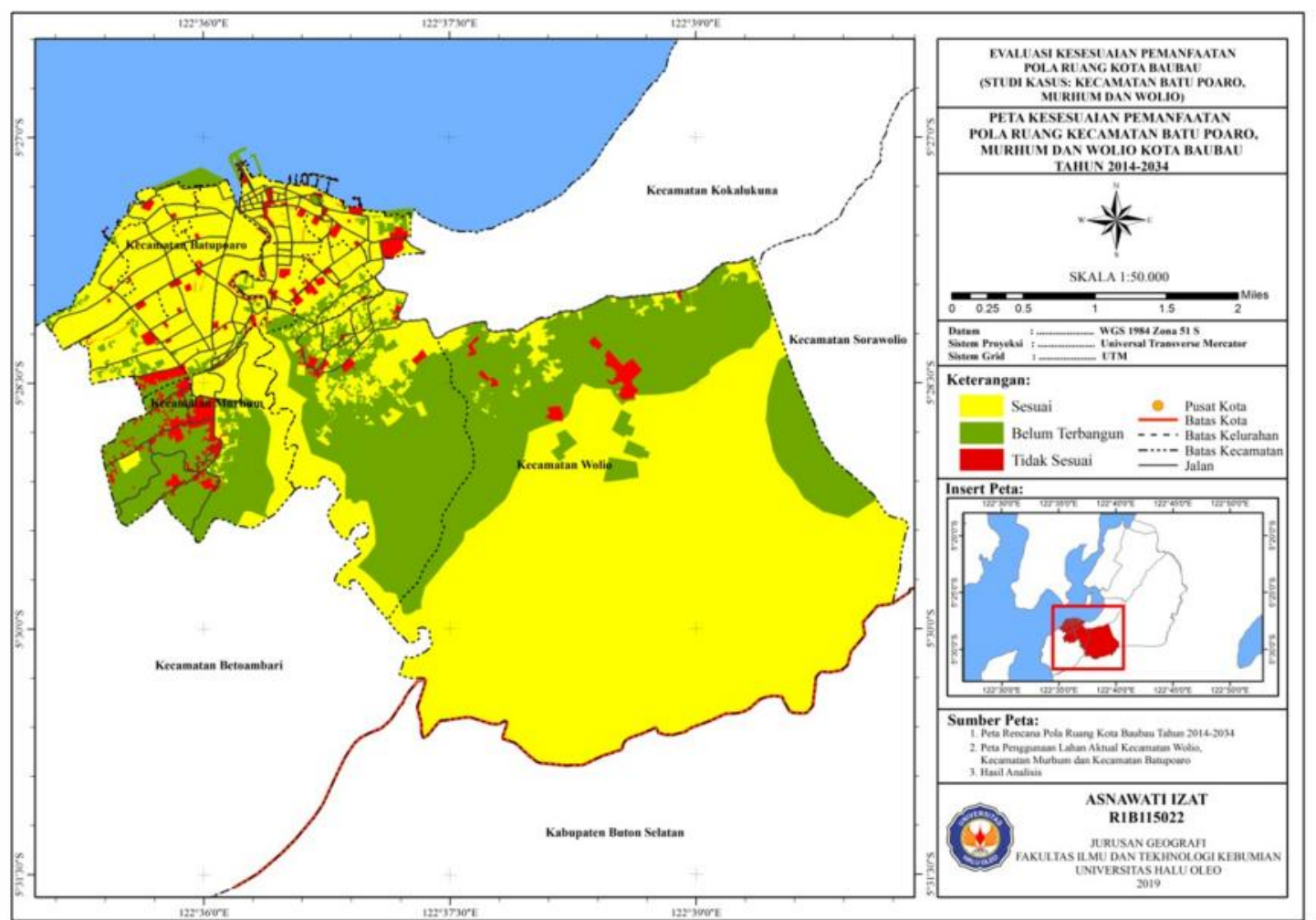

Gambar 4. Peta Kesesuaian Pemanfaatan Pola Ruang Kecamatan Batupoaro, Murhum dan Wolio Kota Baubau Tahun 2014-2034

\subsection{Besaran penyimpangan} pemanfaatan pola ruang wilayah Kecamatan Batupoaro, Murhum dan Wolio Kota Baubau

Tujuan pertama untuk mengetahui besaran penyimpangan pemanfaatan pola ruang pada penelitian ini dapat terjawab berdasarkan hasil analisis diatas, dimana besaran penyimpangan pada kecamatan Batupoaro, Murhum dan Wolio secara keseluruhan yaitu seluas 104 ha atau 3\% dari luas perencanaan. Adapun jika dilihat dari hasil keseluruhan simpangan yang terjadi, maka dapat diterjemahkan bahwa pada lokasi penelitian masuk dalam klasifikasi simpangan rendah dengan nilai 
3, namun jika dilihat per indikator, masih sangat didominasi pada klasifikasi kesesuaian sempurna dengan nilai 4 , dan hanya terdapat 2 indikator rencana pola ruang yang masuk kategori klasifikasi simpangan rendah dengan nilai 3 yaitu pada indikator rencana kawasan perkantoran dan perumahan.

\subsection{Faktor-Faktor yang Mempengaruhi Penyimpangan Pemanfaatan Pola Ruang Wilayah Kecamatan Batupoaro, Murhum dan Wolio}

Faktor-faktor yang menyebabkan penyimpangan pola ruang pada penelitian ini ditetapkan dan dibatasi menjadi tiga faktor penyebab yang di analisis menggunakan alat analisis uji regresi linear berganda dengan variabel dummy. Variabel Y pada penelitian ini merupakan Penyimpangan Pola Ruang sedangkan variabel D1 adalah Sosialisasi, variabel D2 yakni Perizinan dan Variabel D3 adalah Sanksi. Adapun untuk mengetahui seberapa besar variabel independen (D) mempengaruhi variabel dependen (Y), maka penelitian ini menggunakan uji determinasi, Uji F (Uji Simultan), serta Uji Koefisien Regresi (Uji Parsial).

\section{Uji Determinasi $\left(\mathbf{R}^{2}\right)$}

Hasil analisis uji regresi linear berganda yang mengukur nilai koefisien determinasi antara variabel $\mathrm{D}$ dan $\mathrm{Y}$ dapat dilihat pada Tabel 1 .

Tabel 1. Koefisien Determinasi $\left(\mathrm{R}^{2}\right)$

\begin{tabular}{|c|c|c|c|c|}
\hline \multicolumn{5}{|c|}{ Model Summary } \\
\hline Model & $\mathrm{R}$ & $\begin{array}{c}\mathrm{R} \\
\text { Square }\end{array}$ & $\begin{array}{l}\text { Adjusted } \\
\text { R Square }\end{array}$ & $\begin{array}{l}\text { Std. Error of } \\
\text { the Estimate }\end{array}$ \\
\hline 1 & $.393^{\mathrm{a}}$ & .154 & .138 & .82961 \\
\hline & $\begin{array}{l}\text { Has } \\
\text { Tah }\end{array}$ & $\begin{array}{l}\text { sil Anali } \\
\text { hun } 2019\end{array}$ & isis Pengo & han Data \\
\hline
\end{tabular}

Hasil analisis uji regresi linear berganda pada penelitian ini menunjukan bahwa nilai koefisien determinasi $\left(\mathrm{R}^{2}\right)$ bernilai 0,154 . Artinya bahwa besaran nilai presentase variabel sosialisasi (D1), 18 --- April perizinan (D2) dan variabel sanksi (D3) secara keseluruhan dapat menjelaskan variabel penyimpangan ruang (Y) di Kecamatan Batupoaro, Murhum dan Wolio sebesar $15,4 \%$ sedangkan sisanya yakni $84,6 \%$ dijelaskan oleh variabel lain yang tidak dimasukan dalam model regresi.

\section{Uji F (Uji Simultan)}

Uji F dilakukan untuk mengetahui pengaruh variabel independen secara bersama-sama (simultan) terhadap variabel dependennya. Hasil analisis regresi linear berganda nilai signifikansi dari Uji $F$ disajikan pada Tabel 2.

Tabel 2. Hasil Uji F

\begin{tabular}{|c|c|c|c|c|c|}
\hline \multicolumn{6}{|c|}{ ANOVA $^{b}$} \\
\hline Model & $\begin{array}{l}\text { Sum of } \\
\text { Squares }\end{array}$ & df & $\begin{array}{l}\text { Mean } \\
\text { Square }\end{array}$ & $\mathrm{F}$ & Sig. \\
\hline Regression & 5.107 & 3 & 1.702 & 2.474 & $.071^{\mathrm{a}}$ \\
\hline Residual & 38.543 & 56 & .688 & & \\
\hline Total & 43.650 & 59 & & & \\
\hline Sumber: & $\begin{array}{l}\text { Hasil An } \\
\text { Tahun } 201\end{array}$ & $\begin{array}{l}\text { alisis } \\
9\end{array}$ & Pengo & lahan & Data \\
\hline
\end{tabular}

Hasil analisis uji regresi linear berganda pada Tabel 2 menunjukan bahwa nilai signifikansi Uji F sebesar 0,071. Hasil penelitian ini menunjukkan bahwa variabel independen secara simultan berpengaruh signifikan terhadap variabel dependen pada tingkat kepercayaan 90\% $(\mathrm{P}<0,1)$, dengan kata lain faktor-faktor yang ditentukan dalam penelitian ini yakni variabel independen (sosialisasi, perizinan dan sanksi) secara bersama-sama mempengaruhi variabel penyimpangan ruang (Y) secara signifikan di Kecamatan Batupoaro, Murhum dan Wolio.

\section{Uji Koefisien Regresi}

Hasil analisis regresi linear berganda koefisien regresi variabel independen terhadap variabel dependen dapat dilihat pada Tabel 3. 
Tabel 3. Hasil Uji Koefisien Regresi Coefficients $^{\mathrm{a}}$

\begin{tabular}{|c|c|c|c|c|c|}
\hline \multirow[b]{2}{*}{ Model } & \multicolumn{2}{|c|}{$\begin{array}{l}\text { Unstandardized } \\
\text { Coefficients }\end{array}$} & $\begin{array}{l}\text { Standardized } \\
\text { Coefficients }\end{array}$ & \multirow[b]{2}{*}{$\mathrm{t}$} & \multirow[b]{2}{*}{ Sig. } \\
\hline & B & $\begin{array}{l}\text { Std. } \\
\text { Error }\end{array}$ & Beta & & \\
\hline 1 (Constant) & 2.354 & .444 & & 5.305 & .000 \\
\hline Sosialisasi & .180 & .300 & .079 & .601 & .550 \\
\hline Perizinan & -.583 & .215 & -.335 & -2.708 & .009 \\
\hline Sanksi & .324 & .220 & .190 & 1.471 & .147 \\
\hline
\end{tabular}

Sumber: Hasil Analisis Pengolahan Data Tahun 2019

Hasil uji koefisien regresi sebagaimana ditunjukan pada Tabel 3 dapat dituliskan dalam bentuk persamaan regresi sebagai berikut:

$Y=\alpha+\beta 1 D 1-\beta 2 D 2+\beta 3 D 3$

$Y=2,354$ + 0,180 D1 - 0,583 D2 + 0,324 D3

Penjelasan dari persamaan hasil uji koefisien regresi, yaitu:

1.Nilai konstanta $(\boldsymbol{\alpha})$ sebesar 2,354 artinya bahwa jika tidak ada kegiatan sosialisasi, perizinan dan penerapan sanksi, maka nilai skoring penyimpangan pemanfaatan pola ruang di Kecamatan Batupoaro, Murhum dan Wolio adalah sebesar 2,354.

2.Nilai koefisien regresi ( $\boldsymbol{\beta} \mathbf{1})$ adalah 0,180 menyatakan bahwa setiap ada pelaksanaan kegiatan sosialisasi, maka justru meningkatkan potensi penyimpangan pemanfaatan pola ruang sebesar 0,180. Artinya bahwa kegiatan sosialisasi tidak menurunkan potensi penyimpangan pemanfaatan pola ruang karena sosialisasi jarang dilakukan, bahkan terdapat wilayah kecamatan yang tidak pernah ada kegiatan sosialisasi tentang perencanaan pemanfaatan pola ruang. Nilai signifikansi yang diperoleh sebesar $0,550 \quad(\mathrm{P}>0,1) \quad$ artinya kegiatan sosialisasi tidak mempengaruhi penyimpangan pemanfaatan pola ruang, sehingga disimpulkan bahwa hipotesis $\left(\mathrm{H}_{1}\right)$ yang menyatakan variabel sosialisasi berpengaruh secara signifikan terhadap penyimpangan ruang ditolak.
3. Nilai koefisien regresi ( $\beta 2)$ adalah $-0,583$ menyatakan bahwa setiap kali ada perizinan, maka akan mengurangi penyimpangan pemanfaatan ruang sebesar 0,583 . Hal ini dapat pula dilihat pada nilai signifikansinya yaitu sebesar $0,009 \quad(\mathrm{P}<0,05)$ artinya bahwa izin pemanfaatan ruang sangat berpengaruh dapat menurunkan penyimpangan pemanfaatan pola ruang. Oleh karena itu dapat disimpulkan bahwa hipotesis $\left(\mathrm{H}_{1}\right)$ yang menyatakan variabel perizinan berpengaruh secara signifikan terhadap penyimpangan ruang diterima.

4.Nilai koefisien regresi (ß3) 0,324 menyatakan bahwa setiap kali ada penerapan sanksi, maka justru menambah penyimpangan pemanfaatan ruang sebesar 0,324. Nilai signifikansi yang diperoleh sebesar 0,147 menunjukkan bahwa penerapan sanksi tidak berpengaruh terhadap penurunan penyimpangan pemanfaatan ruang, sehingga dapat disimpulkan juga bahwa hipotesis $\left(\mathrm{H}_{1}\right)$ yang menyatakan variabel sanksi berpengaruh secara signifikan terhadap penyimpangan ruang ditolak.

\section{KESIMPULAN}

Berdasarkan hasil analisis spasial, besaran kesesuaian pemanfaatan pola ruang pada kecamatan Batupoaro, Murhum dan Wolio yang mendominasi yaitu klasifikasi sesuai seluas 2.438 ha $(67 \%)$ dari luas wilayah perencanaan dan klasifikasi belum terbangun seluas 1.097 ha (30\%), sedangkan klasifikasi tidak sesuai sangat kecil hanya seluas 104 ha (3\%). Besaran penyimpangan pemanfaatan pola ruang secara keseluruhan mendapat kategori penilaian 3, maka dapat diterjemahkan bahwa pada lokasi penelitian masuk dalam klasifikasi simpangan rendah.

Hasil penelitian menggunakan analisis regresi linear berganda menunjukan bahwa faktor yang paling signifikan mempengaruhi penyimpangan pola ruang adalah faktor perizinan, sedangkan variabel sanksi dan sosialisasi tidak 
berpengaruh terhadap penurunan penyimpangan pola ruang di Kecamatan Batupoaro, Murhum dan Wolio.

\section{DAFTAR PUSTAKA}

Badan Informasi Geospasial. 2014. Peraturan Kepala Badan Informasi Geospasial Nomor 3 Tahun 2014 Pedoman Teknis Pengumpulan dan Pengolahan Data Geospasial Mangrove. 12 Februari 2014. Cibinong.

Badan Pusat Statistik. 2018. Kota Baubau Dalam Angka 2018. Septermber. Baubau: BPS Baubau.

Badan Pusat Statistik. 2015. Kota Baubau Dalam Angka 2015. Juli. Bubau: BPS Baubau.

Mizan, Rahmat Azul., Weka Widayati, dan Jamal Harimudin. 2017. Pola Spasial Persebaran Tingkat Kerentanan Wilayah Terhadap Penyakit Demam Berdarah Dengue (DBD). Kasus Kota Baubau, Provinsi Sulawesi Tenggara. Jurnal Geografi Aplikasi dan Teknologi, Vol. 1, No. 1, p. 23-32.
Muhajir, Ahmad. 2017. Kebijakan Pengendalian Pemanfaatan Ruang di Kota Baubau Provinsi Sulawesi Tenggara. Jurnal Renaissance, Vol. 2, No.2, p. 184-193.

Nawangwulan, Nila Hapsari., Bambang Sudarsono, dan Bandi Sasmito. 2013. Analisis Pengaruh Perubahan Lahan Pertanian Terhadap Hasil Produksi Tanaman Pangan Di Kabupaten Pati Tahun 2001 - 2011. Jurnal Geodesi Undip, Vol 2, No.2, p. 127-140.

Sulistyono dan Wiwik Sulistiyowati. 2018. Peramalan Produksi Dengan Metode Regresi Linier Berganda. Jurnal PROZIMA (Productivity, Optimization and Manufacturing System Engineering), Vol.1, No.2, p.82-89.

Undang-Undang Republik Indonesia Nomor 26 Tahun 2007 Penataan Ruang. 26 April 2007. Lembar Negara Republik Indonesia Tahun 2007 Nomor 68. Jakarta. 